\title{
EFFECT OF PLANTING DATES AND RATES OF NITROGEN AND POTASSIUM FERTILIZATION ON GROWTH AND PRODUCTIVITY OF GIZA 96 COTTON VARIETY
}

\author{
EI-D. El-D. Deshish, S.A.F. Hamoda and Azza A.M. El-Hendawy \\ Department of Agronomy, Cotton Research Institute, \\ Agricultural Research Center, Egypt.
}

Received: Dec. 6, 2019

Accepted: Dec. 13, 2020

\begin{abstract}
Two field experiments were conducted at Sakha Agricultural Research Station at Kafr El-Sheikh Governorate, Egypt, during the growing seasons of 2018 and 2019 to study the effect of planting dates and rates of nitrogen and potassium fertilization on growth and productivity of Giza 96 cotton variety to preparing the optimal agricultural recommendation for it. The experiment design was a split plot with four replications. The main plots had two planting dates (Early at $15^{\text {th }}$ April and Late at $15^{\text {th }}$ May) and the sub plots had four rates of nitrogen and potassium fertilization (125\% from the recommended dose for nitrogen $(N)+$ potassium $(K), 100 \% N+K, 75 \% N+K, 50 \% N$ $+\mathrm{K}$ ). (The recommended dose $60 \mathrm{~kg}$ Nitrogen/fed. $+24 \mathrm{~kg}$ Potassium/fed.) The most important results obtained could be summarized as follows: Planting dates had a significant effect on growth, yield and its components and fiber properties. Early planting date significantly increased No. of fruiting branches/plant, No. of open bolls /plant, boll weight, seed cotton yield/fed. and gave good fiber properties. The rates of nitrogen and potassium fertilization had significant effect on growth traits, yield and yield components while did not exhibit any significant effect on fiber properties. The rate $100 \% \mathrm{~N}+\mathrm{K}(60 \mathrm{~kg}$ $\mathrm{N}+24 \mathrm{~kg} \mathrm{~K}$ ) significantly increased No. of fruiting branches /plant, No. of open bolls /plant, boll weight, seed index and seed cotton yield/fed. The interaction between planting dates and rates of nitrogen and potassium fertilization had significant effect on growth, yield and its components while did not exhibit any significant effect on lint $\%$ and fiber properties. Generally, early planting in combination with the rate $100 \% \mathrm{~N}+\mathrm{K}(60 \mathrm{~kg} \mathrm{~N}+24 \mathrm{~kg}$ $\mathrm{K}$ ) significantly increased number of fruiting branches /plant, number of open bolls /plant, boll weight, seed index and seed cotton yield/fed and gave high productivity of Egyptian cotton variety Giza 96.
\end{abstract}

Key words: Cotton, Planting dates, Fertilizer, Nitrogen, Potassium, Growth, Yield and fiber properties.

\section{INTRODUCTION}

Planting cotton in a suitable time leads to forming the first fruiting branch at a lower node on the stem and only an optimum height, increasing no. of bolls and yield of cotton, escaping from leaf and boll-worms and aphids at the end of the season and picking early. Boquet et al. (2003) showed that the excessive plant height at late planting date was partly responsible for lower yield as the crop used a larger portion of its energy budget for vegetative growth and the excess plant height caused lodging. Seed cotton yield/fed. was significantly decreased with delayed planting. Hamoda (2006) found that late sown plants grew faster than early sown ones. Boll weight, no. of open bolls/plant and seed cotton yield/fed. increased in early planting date. Arshad et al., (2007) reported that early planting produced $23 \%$ more open bolls and $18 \%$ more cotton yield. Bange et al., (2008) indicated that early sown cotton produces taller plants with higher 
number of branches, number of bolls and yield. Emara et al., (2015) found that early planting date significantly increased seed cotton yield/fad. due to the increase of number of open bolls/plant and boll weight. However, Emara (2012) indicated that sowing date gave significant effects on upper half mean length and micronaire reading in favour of early planting. While, did not exhibit any significant on uniformity index and strength. Deshish et al., (2015) indicated that all fiber properties studied were improved due to early planting of cotton.

Nitrogen is one of the most important element in cotton plants. Moderate levels of nitrogen fertilization may produce a higher yield and quality, but higher levels may result in excessive of vegetative growth with a lower yield and quality. Through cotton agronomy programs, many traits are usually assigned to determine the optimum nitrogen levels fertilization must apply for every new promising hybrid cotton and commercial varieties. In this respect, several studies were done to evaluate the response of cotton plants to different nitrogen levels. Hamed (2006) indicated that the plant height, no. of fruiting branches/plant, no. of open bolls/plant and seed cotton yield/plant significantly increased by increasing nitrogen levels. Ibrahim (2008) found that plant height, no. of fruiting branches/plant, no. of open bolls/ plant, boll weight, seed index, seed cotton yield/fed., fiber length, fiber strength and micronaire values increased significantly by increased NPK fertilizers levels at $\mathbf{8 0}$ $\mathrm{kg} \mathrm{N} \mathrm{+30} \mathrm{kg} \mathrm{P205} \mathrm{+48} \mathrm{kg} \mathrm{k20/fed.}$ Policepatil et al., (2009) revealed that increased NPK fertilization to cotton may result in more accumulation of photosynthetic assimilates that resulted in higher fruit weight. El-Shahawy and Hamoda (2011) found that plant height, no. of sympodia /plant, first sympodial position, no. of open bolls /plant, boll weight, seed index and seed cotton yield/fed. increased by increasing nitrogen levels and also found that the studied treatments did not exhibit any significant effect on all fiber properties Hamoda et al., (2014) found that the final plant height, No. of fruiting branches/plant, No. of bolls/plant, boll weight, seed index and seed cotton yield/fad. increased with increasing rates of NPK applied.. Elhamamsey et al., (2016) and Emara et al., (2016) revealed that the high NPK fertilizer level did not exhibit significant effect on seed index, lint percentage and fiber properties. Emara and Abdel-Aal (2017) found that the plant height, No. of fruiting branches/plant, No. of bolls/plant, boll weight, seed index, seed cotton yield/ fed. increased with increasing rates of NPK applied.

Potassium is an essential macroelement required in large amounts for normal plant growth and development. Potassium is an important nutrient that has favorable effects on the metabolism of nucleic acids, proteins, vitamins and growth substances. Furthermore, Potassium plays important roles in the translocation of photsynthates, sugars and activation of many enzymes required from sources to sinks Morteza et al., (2005). However, Pettigrew (1999) indicated that the elevated carbohydrate concentrations remaining in source tissue, such as leaves, appear to be part of the overall effect of potassium deficiency in reducing the amount of photosynthetic available for reproductive sinks and thereby producing changes in the yield and quality of cotton. Many studies have shown increased yield and productivity in response to potassium fertilization as reported by Abou-Zaid et al., (2009), Emara and Hamoda (2012), Gomaa et al., (2014), Abdel-Aal et al., (2015) and Emara (2015). The main purpose of this study was to preparing the suitable agricultural managements practices (planting date and rates of nitrogen and Potassium fertilization to Giza 96 cotton variety. 


\section{MATERIALS AND METHODS}

Two field experiments were conducted at Sakha Agricultural Research Station at Kafr El-Sheikh Governorate, Egypt, during the growing seasons of 2018 and 2019 to study the effect of planting dates and rates of nitrogen and potassium fertilization on growth and productivity of Giza 96 cotton variety. The experiment design was a split plot with four replications. The main plots had two planting dates; (Early at $15^{\text {th }}$ April and Late at $15^{\text {th }}$ May) and the sub plots had four rates of nitrogen and potassium fertilization (125\% from the recommended dose for nitrogen (N) + potassium (K), 100
$\% \mathbf{N}+\mathrm{K}, 75 \% \mathbf{N}+\mathrm{K}, 50 \% \mathbf{N}+\mathrm{K}$ ). (The recommended dose equal $60 \mathrm{~kg}$ Nitrogen/fed. + 24 kg Potassium/fed.). Characters of Giza 96 variety are showed in Table (1).

The sub-plot size was $19.5 \mathrm{~m}^{2}$ including six rows $(5 \mathrm{~m}$ long and $0.65 \mathrm{~cm}$ width). Cottonseeds were sown after two cuts of Egyptian clover Barseem (Trifolium alexandrinum L.,) in 2018 and 2019 seasons. Soil samples was taken in the two seasons before planting to estimate the soil characters using the standard methods as described by Chapman and Parker (1981). The results are shown in Table (2).

Table (1): Characters of the Giza 96 variety.

\begin{tabular}{|l|l|}
\hline Genotype name & Giza 96 \\
\hline Species & Barbadense. \\
\hline Category & Extra long staple and extra fine. \\
\hline Pedigree & GGiza 84 x (Giza70 x Giza 51B)\} x C62 \\
\hline Characteristics & $\begin{array}{l}\text { Extra long staple variety characterized by high yielding, earliness, } \\
\text { resistance to Fusarium wilt, high lint percentage (\%) about 38\%. }\end{array}$ \\
\hline $\begin{array}{l}\text { Botanical } \\
\text { distinguishing } \\
\text { characters }\end{array}$ & $\begin{array}{l}\text { The stem has a length with resistance to lodging and also has a } \\
\text { green color mixed by dim red with internodes length ranged from } \\
\text { short to medium. The leaves have navicular shape; medium size } \\
\text { with medium lobes and leather feel. The node of the first fruiting } \\
\text { branch ranged from 7-8, the axillaries buds will activate to give a } \\
\text { fruiting branch which ended with one or two bolls. Flower petals } \\
\text { has shape like a tubular, the petals is rolling. The boll shape is } \\
\text { conical shape with shoulder and many glands. Seed is medium- } \\
\text { sized and the fuzz cover about 1/4 to 1/2 from the whole size and } \\
\text { fuzz color is gray-greenish. }\end{array}$ \\
\hline Hybrid bred by & $\begin{array}{l}\text { Breeding Res. Section, Cotton Res. Inst., Agric. Res. Center, Giza, } \\
\text { Egypt. }\end{array}$ \\
\hline
\end{tabular}

Table (2): Mechanical and chemical analysis of the experiment soil in 2018 and 2019 seasons.

\begin{tabular}{|c|c|c|c|c|c|c|c|c|}
\hline \multirow{2}{*}{ Season } & \multirow[t]{2}{*}{ Texture } & \multirow[t]{2}{*}{ pH } & \multirow{2}{*}{$\begin{array}{c}\text { Organic } \\
\text { Matter (\%) }\end{array}$} & \multirow{2}{*}{$\begin{array}{c}\text { EC } \\
(\mathrm{m} \\
\mathrm{mhos} / \mathrm{cm})\end{array}$} & \multirow{2}{*}{$\begin{array}{c}\text { Bicarbonate } \\
(\%)\end{array}$} & \multicolumn{3}{|c|}{$\begin{array}{l}\text { Available elements } \\
\qquad(\mathrm{ppm})\end{array}$} \\
\hline & & & & & & $\mathbf{N}$ & $\mathbf{P}$ & K \\
\hline 2018 & Clay loam & 8.29 & 1.66 & 0.66 & 2.01 & 22.72 & 14.70 & 245.0 \\
\hline 2019 & Clay loam & 8.38 & 1.81 & 0.72 & 2.00 & 20.32 & 12.53 & 230.0 \\
\hline
\end{tabular}


In both seasons, the soil texture was clay loam, low content of organic matter, low calcium carbonate and non-saline. The soils of the two seasons were low in total N, Extractable-P, and low to medium in available $\mathrm{K}$. Hills were spaced at $30 \mathrm{~cm}$ and seedlings were thinned at 2 plants/hill after 35 day from planting. Phosphorus fertilizer as ordinary superphosphate $\left(15.5 \% \quad \mathrm{P}_{2} \mathrm{O}_{5}\right)$ at the rate of $22.5 \mathrm{~kg} \mathrm{P2O5} / \mathrm{fed}$. was incorporated during seed bed preparation. Nitrogen fertilizer in the form of ammonium nitrate $(33.5 \% \mathrm{~N})$ at the tested rates was applied in two equal doses, immediately before the first and the second irrigations. Potassium fertilizer in the form of potassium sulphate $(48 \% \mathrm{~K} 20)$ at the tested rates was side-dressed in a single dose before the second irrigation. The other standard agricultural practices were followed throughout the two growing seasons. five representative hills (10 plants/sub-main plot) were taken at random in order to study the following traits; plant height at harvest $(\mathrm{cm})$, number of fruiting branches /plant, number of open bolls/plant, boll weight (g), lint \% and seed index (100 seed weight) (g). The yield of seed cotton in kentars/fed. was estimated from the three inner ridges, (One kentar $=157.5 \mathrm{~kg}$.). Samples of lint cotton under different treatments were tested at the laboratories of the Cotton Technology Research Division, Cotton Research Institute in Giza to determine fiber properties, under controlled conditions of $65 \% \pm 2$ of relative humidity and $21^{\circ} \pm 2$ Co temperature. Fiber length and uniformity index, fiber strength and Micronaire reading were determined on digital Fibrograph instrument 630, Pressley instrument and Micronaire instrument 675 respectively, according to A.S.T.M. (2012). All collected data were subjected to statistical analysis as proposed by Gomez and Gomez (1984) and means were compared by LSD and $F$ test at $5 \%$ level of probability.

\section{RESULTS AND DISCUSSION}

The results of growth traits as affected by planting dates, rates of nitrogen and potassium fertilization and its interaction of cotton during 2018 and 2019 seasons were shown in Table (3). Data showed that planting dates had a significant effect on plant height at harvest and number of fruiting branches /plant in 2018 and 2019 seasons. Late planting date had significantly increased plant height compared with early planting. However, early planting date had significantly increased number of fruiting branches /plant. This effect may be due to the balance between vegetative and fruiting growth, which occurred under the earlier date, than late one. Similar results were obtained by Emara et al., (2016), Emara (2012), Emara et al., (2015).

Also data in Table (3) indicate that rates of nitrogen and potassium fertilization had significant effect on growth traits (plant height and number of fruiting branches /plant) in both seasons. The high rate $125 \% \mathrm{~N}+\mathrm{K}$ rate significantly increased plant height while, the rate $100 \% \quad \mathrm{~N}+\mathrm{K}$ significantly increased number of fruiting branches /plant in both seasons as compared with the other treatments. The positive response due to the high rate $125 \% \mathrm{~N}+\mathrm{K}$ on growth is mainly related to the followings; $N$ plays an important role in synthesis, distributing and accumulating the important substances responsible for growth and reflected greatly on plant dry weight (Hearn, 1981). These results are in harmony with those obtained by Elhamamsey et al., (2016), Emara et al., (2016) and Emara and Abdel-Aal (2017), which found that plant height and number of fruiting branches/plant were significantly increased by increasing 
NPK rate. Data in Table (3) indicate that the interaction between planting dates and rates of nitrogen and potassium fertilization treatments had significant effect on plant height and number of fruiting branches /plant in 2018 and 2019 seasons. Late planting date and high rate $125 \% \mathrm{~N}+\mathrm{K}$ gave tallest plant height in both seasons, while in early planting date with high rate $100 \% \mathrm{~N}+\mathrm{K}$ gave good value of number of fruiting branches /plant as compared with the other treatments.

The results of yield and its components as affected by planting dates, rates of nitrogen and potassium fertilization and its interaction of cotton during 2018 and 2019 seasons were shown in Table (4). Data cleared that early planting date were significantly increased number of open bolls/plant, boll weight, seed index and seed cotton yield/fad. in both seasons, while lint percentage were insignificantly affected by planting dates. This could be attributed to the increase in the number fruiting branches /plant and the well-built plants, which were shorter and had lower fruiting node than the late planting, which were etiolated. This in turn might have had increased the amounts of available photosynthates for boll development and hence increased No. of open bolls/plant and boll weight. The seed cotton yield/fad. was increased in favor of early sowing as a result of increasing number of open bolls/plant and boll weight. These results are in harmony with those obtained by Emara et al., (2016), Emara et al., (2015) and Deshish et al., (2015).

Table (3): Effect of planting dates, rates of nitrogen and potassium fertilization and its interaction on growth of cotton during 2018 and 2019 seasons.

\begin{tabular}{|c|c|c|c|c|c|}
\hline \multicolumn{2}{|c|}{ Treatments } & \multicolumn{2}{|c|}{$\begin{array}{l}\text { Plant height } \\
\text { at harvest }(\mathrm{cm})\end{array}$} & \multicolumn{2}{|c|}{$\begin{array}{c}\text { No. of fruiting } \\
\text { branches /plant }\end{array}$} \\
\hline Planting dates (A) & $\begin{array}{c}\text { Rates of N+k } \\
\text { fertilization (B) }\end{array}$ & 2018 & 2019 & 2018 & 2019 \\
\hline \multirow{4}{*}{ Early } & $125 \% \mathrm{~N}+\mathrm{K}$ & 147.67 & 148.03 & 13.80 & 13.87 \\
\hline & $100 \% \mathrm{~N}+\mathrm{K}$ & 144.00 & 146.00 & 14.97 & 14.93 \\
\hline & $75 \% \mathrm{~N}+\mathrm{K}$ & 143.00 & 144.83 & 12.53 & 12.70 \\
\hline & $50 \% \mathrm{~N}+\mathrm{K}$ & 141.00 & 143.73 & 12.53 & 12.33 \\
\hline \multicolumn{2}{|c|}{ Mean } & 143.92 & 145.65 & 13.46 & 13.46 \\
\hline \multirow{4}{*}{ Late } & $125 \% \mathrm{~N}+\mathrm{K}$ & 155.00 & 155.80 & 11.37 & 11.73 \\
\hline & $100 \% \mathrm{~N}+\mathrm{K}$ & 153.00 & 152.73 & 11.87 & 11.93 \\
\hline & $75 \% \mathrm{~N}+\mathrm{K}$ & 151.00 & 151.77 & 10.67 & 10.63 \\
\hline & $50 \% \mathrm{~N}+\mathrm{K}$ & 147.00 & 146.33 & 10.60 & 10.30 \\
\hline \multicolumn{2}{|c|}{ Mean } & 151.50 & 151.66 & 11.13 & 11.15 \\
\hline \multirow{4}{*}{$\begin{array}{c}\text { General means of } \\
\text { rates of } N+K \\
\text { fertilization }(B)\end{array}$} & $125 \% \mathrm{~N}+\mathrm{K}$ & 151.33 & 151.92 & 12.59 & 12.80 \\
\hline & $100 \% \mathrm{~N}+\mathrm{K}$ & 148.50 & 149.37 & 13.42 & 13.43 \\
\hline & $75 \% \mathrm{~N}+\mathrm{K}$ & 147.00 & 148.30 & 11.60 & 11.67 \\
\hline & $50 \% N+K$ & 144.00 & 145.03 & 11.57 & 11.32 \\
\hline F test for & A & * & ** & $* *$ & $* *$ \\
\hline \multirow{2}{*}{ L.S.D. at $5 \%$ for } & B & 0.36 & $\because r r$ & 0.17 & 0.13 \\
\hline & $A \times B$ & 0.60 &.$\$ 1$ & $0 . r_{1}$ & $0 . r 7$ \\
\hline
\end{tabular}


El-D. El-D. Deshish, et al.,

Table (4): Effect of planting dates, rates of nitrogen and potassium fertilization and its interaction on yield and its components of cotton during 2018 and 2019 seasons.

\begin{tabular}{|c|c|c|c|c|c|c|c|c|c|c|c|}
\hline \multicolumn{2}{|c|}{ Treatments } & \multicolumn{2}{|c|}{$\begin{array}{c}\text { No. of } \\
\text { open } \\
\text { bolls/plant }\end{array}$} & \multicolumn{2}{|c|}{$\begin{array}{c}\text { Boll weight } \\
\text { (g) }\end{array}$} & \multicolumn{2}{|c|}{ Lint \% } & \multicolumn{2}{|c|}{$\begin{array}{l}\text { Seed index } \\
\text { (g) }\end{array}$} & \multicolumn{2}{|c|}{$\begin{array}{c}\text { Seed } \\
\text { cotton } \\
\text { yield } \\
\text { (Ken./fad.) }\end{array}$} \\
\hline $\begin{array}{l}\text { Planting dates } \\
\text { (A) }\end{array}$ & $\begin{array}{c}\text { Rates of } \\
N+K \\
\text { fertilization } \\
\text { (B) }\end{array}$ & 2018 & 2019 & 2018 & 2019 & 2018 & 2019 & 2018 & 2019 & 2018 & 2019 \\
\hline \multirow{4}{*}{ Early } & $125 \% N+K$ & 18.60 & 16.57 & 2.44 & 2.40 & 38.30 & 38.67 & 9.77 & 9.80 & 7.60 & 7.50 \\
\hline & $100 \% \mathrm{~N}+\mathrm{K}$ & 19.57 & 18.70 & 2.63 & 2.61 & 38.50 & 38.54 & 9.80 & 9.95 & 8.97 & 8.73 \\
\hline & $75 \% \mathrm{~N}+\mathrm{K}$ & 16.70 & 15.60 & 2.35 & 2.27 & 38.65 & 38.82 & 9.60 & 9.70 & 7.37 & 7.13 \\
\hline & $50 \% \mathrm{~N}+\mathrm{K}$ & 15.27 & 13.73 & 2.03 & 2.09 & 38.75 & 38.93 & 9.55 & 9.53 & 6.62 & 6.20 \\
\hline \multicolumn{2}{|c|}{ Mean early sowing } & 17.53 & 16.15 & 2.36 & 2.34 & 38.55 & 38.74 & 9.68 & 9.75 & 7.64 & 7.39 \\
\hline \multirow{4}{*}{ Late } & $125 \% \mathrm{~N}+\mathrm{K}$ & 12.33 & 12.00 & 1.69 & 1.66 & 38.35 & 38.60 & 9.42 & 9.60 & 5.40 & 5.27 \\
\hline & $100 \% \mathrm{~N}+\mathrm{K}$ & 13.83 & 13.23 & 1.77 & 1.72 & 38.61 & 38.70 & 9.45 & 9.65 & 6.13 & 5.87 \\
\hline & $75 \% \mathrm{~N}+\mathrm{K}$ & 12.83 & 12.40 & 1.88 & 1.78 & 38.67 & 38.91 & 9.20 & 9.51 & 6.67 & 6.53 \\
\hline & $50 \% \mathrm{~N}+\mathrm{K}$ & 12.63 & 12.23 & 1.65 & 1.61 & 38.80 & 38.96 & 9.15 & 9.33 & 5.70 & 5.53 \\
\hline \multicolumn{2}{|c|}{ Mean late sowing } & 12.91 & 12.47 & 1.75 & 1.69 & 38.61 & 38.79 & 9.31 & 9.52 & 5.98 & 5.80 \\
\hline \multirow{4}{*}{$\begin{array}{l}\text { General means } \\
\text { of rates of } N+K \\
\text { fertilization }(B)\end{array}$} & $125 \% N+K$ & 15.47 & 14.28 & 2.06 & 2.03 & 38.33 & 38.64 & 9.60 & 9.70 & 6.50 & 6.38 \\
\hline & $100 \% \mathrm{~N}+\mathrm{K}$ & 16.70 & 15.97 & 2.20 & 2.16 & 38.56 & 38.62 & 9.63 & 9.80 & 7.55 & 7.30 \\
\hline & $75 \% \mathrm{~N}+\mathrm{K}$ & 14.77 & 14.00 & 2.12 & 2.03 & 38.66 & 38.87 & 9.40 & 9.61 & 7.02 & 6.83 \\
\hline & $50 \% \mathrm{~N}+\mathrm{K}$ & 13.95 & 12.98 & 1.84 & 1.85 & 38.78 & 38.95 & 9.35 & 9.43 & 6.16 & 5.87 \\
\hline$F$ test for & A & $* *$ & $* *$ & * & $*$ & N.S & N.S & * & * & $* *$ & $* *$ \\
\hline \multirow{2}{*}{ L.S.D. at $5 \%$ for } & B & 0.36 &..$\leqslant \leqslant$ & 0.08 & $\because .7$ & N.S & N.S & $. .1 \leqslant$ &. .19 & $\because$. &. .47 \\
\hline & $A \times B$ & 0.49 &. $.0 Y$ & 0.21 &. .11 & N.S & N.S &..$\times q$ &..$\leqslant 1$ & $\cdot r \varepsilon$ &..$\leqslant 9$ \\
\hline
\end{tabular}

The results in Table (3) show that rates of nitrogen and potassium fertilization had a significant effect on number of open bolls/plant, boll weight, seed index and seed cotton yield/feddan, while insignificant effect on lint \% in both seasons. The highest values of number of bolls/plant, boll weight and seed cotton yield/feddan were produced from the rate $100 \% \mathrm{~N}+\mathrm{P}$ while the lowest values of number of bolls/plant, boll weight and seed cotton yield/feddan were obtained from the rate $50 \% \mathrm{~N}+\mathrm{P}$ in both season. The positive response to the rate $100 \% N+P$ with regard to yield and its components might be due to the improvement nutrient availability and increases in nutrients uptake. The role of these two concentrations to increase leaf $\mathrm{N}, \mathrm{P}$ and $\mathrm{K}$ content and consequently increase photosynthesis, assimilates accumulation and plant dry weight and the higher number of open bolls/plant and heavier bolls. The boll weight increases due to the high NPK level mainly attributed to increase photosynthetic activity of cotton plants and consequently increase accumulation of metabolites with direct impact on boll weight. These results are in accordance with those outlined by Hamoda et al., (2014), Elhamamsey et al., (2016) and 
Emara and Abdel-Aal (2017). Data in Table (3) indicate that the interaction between planting dates and rates of nitrogen and potassium fertilization had significant effect on number of bolls/plant, boll weight, seed index and seed cotton yield/feddan while had insignificant effect on lint \% in both season. Early planting and the rate $100 \%$ $\mathrm{N}+\mathrm{K}$ gave high number of bolls/plant, boll weight and seed cotton yield/feddan as compared with the other treatments.

Data in Table (5) shown that effect of planting dates, rates of nitrogen and potassium fertilization and its interaction of cotton during 2018 and 2019 seasons on fiber parameters (upper half mean length, uniformity index, fiber strength and micronaire reading). The results in Table (4) indicate that planting dates had significant effect on fiber properties while, rates of nitrogen and potassium fertilization and the interaction between factors did not exhibit any significant effect on fiber properties under study in both seasons. This may be attributed to the realization that these characteristics were less affected by the environmental factors. These results are in accordance with those outlined by Elhamamsey et al., (2016) and Emara et al., (2016).

Table (5): Effect of planting dates, rates of nitrogen and potassium fertilization and its interaction on fiber properties yield and its components of cotton during 2018 and 2019 seasons.

\begin{tabular}{|c|c|c|c|c|c|c|c|c|c|}
\hline \multicolumn{2}{|c|}{ Treatments } & \multicolumn{2}{|c|}{$\begin{array}{l}\text { Upper half } \\
\text { mean }\end{array}$} & \multicolumn{2}{|c|}{$\begin{array}{l}\text { Uniformity } \\
\text { index }\end{array}$} & \multicolumn{2}{|c|}{$\begin{array}{c}\text { Fiber } \\
\text { strength } \\
\text { (Presley } \\
\text { units) }\end{array}$} & \multicolumn{2}{|c|}{$\begin{array}{l}\text { Micronaire } \\
\text { reading }\end{array}$} \\
\hline $\begin{array}{l}\text { Planting dates } \\
\text { (A) }\end{array}$ & $\begin{array}{c}\text { Rates of } \mathrm{N}+\mathrm{K} \\
\text { fertilization }(\mathrm{B})\end{array}$ & 2018 & 2019 & 2018 & 2019 & 2018 & 2019 & 2018 & 2019 \\
\hline \multirow{4}{*}{ Early } & $125 \% \mathrm{~N}+\mathrm{K}$ & 36.90 & 36.87 & 88.62 & 88.70 & 12.27 & 11.99 & 4.20 & 4.23 \\
\hline & $100 \% \mathrm{~N}+\mathrm{K}$ & 37.00 & 37.23 & 88.75 & 88.70 & 12.65 & 12.04 & 4.25 & 4.27 \\
\hline & $75 \% \mathrm{~N}+\mathrm{K}$ & 36.54 & 36.60 & 87.78 & 87.93 & 12.35 & 11.92 & 4.15 & 4.37 \\
\hline & $50 \% \mathrm{~N}+\mathrm{K}$ & 36.25 & 36.10 & 87.70 & 87.73 & 12.25 & 11.70 & 4.13 & 4.10 \\
\hline \multicolumn{2}{|c|}{ Mean early sowing } & 36.67 & 36.70 & 88.21 & 88.27 & 12.38 & 11.91 & 4.18 & 4.24 \\
\hline \multirow{4}{*}{ Late } & $125 \% \mathrm{~N}+\mathrm{K}$ & 35.94 & 35.70 & 87.45 & 87.13 & 11.50 & 11.98 & 4.12 & 4.10 \\
\hline & $100 \% \mathrm{~N}+\mathrm{K}$ & 36.00 & 35.53 & 87.10 & 86.93 & 11.60 & 11.78 & 3.98 & 3.87 \\
\hline & $75 \% \mathrm{~N}+\mathrm{K}$ & 35.54 & 35.30 & 86.65 & 86.40 & 11.75 & 11.79 & 3.92 & 4.07 \\
\hline & $50 \% \mathrm{~N}+\mathrm{K}$ & 35.48 & 34.63 & 86.14 & 86.37 & 11.47 & 11.52 & 3.87 & 4.03 \\
\hline \multicolumn{2}{|c|}{ Mean late sowing } & 35.74 & 35.29 & 86.84 & 86.71 & 11.58 & 11.77 & 3.97 & 4.02 \\
\hline \multirow{4}{*}{$\begin{array}{l}\text { General means } \\
\text { of rates of } N+K \\
\text { fertilization (B) }\end{array}$} & $125 \% \mathrm{~N}+\mathrm{K}$ & 36.42 & 36.29 & 88.04 & 87.92 & 11.89 & 11.99 & 4.16 & 4.17 \\
\hline & $100 \% \mathrm{~N}+\mathrm{K}$ & 36.50 & 36.38 & 87.93 & 87.82 & 12.13 & 11.91 & 4.12 & 4.07 \\
\hline & $75 \% \mathrm{~N}+\mathrm{K}$ & 36.04 & 35.95 & 87.22 & 87.17 & 12.05 & 11.86 & 4.04 & 4.22 \\
\hline & $50 \% \mathrm{~N}+\mathrm{K}$ & 35.87 & 35.37 & 86.92 & 87.05 & 11.86 & 11.61 & 4.00 & 4.07 \\
\hline$F$ test for & A & * & * & $* *$ & ** & * & * & ${ }^{*}$ & ${ }^{*}$ \\
\hline \multirow{2}{*}{ L.S.D. at $5 \%$ for } & B & N.S & N.S & N.S & N.S & N.S & N.S & N.S & N.S \\
\hline & $A \times B$ & N.S & N.S & N.S & N.S & N.S & N.S & N.S & N.S \\
\hline
\end{tabular}




\section{CONCLUSION}

The results obtained in this study could lead us to recommendations package, which seemed to be useful for increasing the cotton yield production and the best fiber quality. It could be concluded the early planting in combination with the rate $100 \% \mathrm{~N}+\mathrm{K}$ fertilizer (60 $\mathrm{kg} \mathrm{N} / \mathrm{fad}$ and $24 \mathrm{~kg} / \mathrm{fed}$.) obtaining the high productivity of Egyptian cotton (Giza 96).

\section{REFERENCES}

A.S.T.M. (2012). American Society for Testing and Materials. Designation, (D1447-07), (D1448-97), (D1445-67).

Abdel-Aal, Amal S.A., M.A.A. Emara and S.A.F. Hamoda (2015). Effect of times and methods of potassium fertilizer on yield and yield components of new hybrid cotton (Giza $86 \times 10229$ ) under early and late sowing. Fayoum J. Agric. Res. \& Dev., January 2015, 30(1): 13 - 26.

Abou-Zaid, M.K., M.A. Emara and S.A.F. Hamoda (2009). Future of Egyptian cotton production in the newly reclaimed desert land of Egypt: 10Cotton response to soil, foliar potassium application and potassium dissolving bacteria (KDB). J. Adv. Agric. Res., (Fac. Agric. Saba Basha), 42(1): 73 - 80.

Arshad, M., A. Wajid, M. Maqsood, K. Hussain and M. Aslam (2007). Response of growth, yield and quality of different cotton cultivars to sowing dates. Pak. J. Agric., 44(2): 208 - 212.

Bange, M., S. Caton and S. Milroy (2008). Managing yields of high fruit retention in transgenic cotton (Gossypium hirsutum L.) using sowing date. Australian J. Agric. Res., 59(8): 733 741.

Boquet, D., J. Caylor and C. Shivers (2003). No-till cotton response to planting date. Proc., Beltwide Cotton
Conf., Nashville TN. U.S.A., (Jan. 6-10) (2): 2045-2047.

Chapman, H.D. and F.P. Parker (1981). Methods of analysis of soil, plants and water. Univ. California, August, 1981. Second Printing.

Deshish, El-D., S.A.F. Hamoda and M.A.A. Emara (2015). Study of new irrigation systems under planting dates to increasing productivity of cotton. Egypt J. of Appl. Sci., 30 (12): 564 573.

Elhamamsey, M.H., E.A. Ali and M.A.A. Emara (2016). Effect of some cultural practices on shedding and yield of Egyptian cotton. Assiut J. of Agric. Sci., 47(4): 41 - 51.

El-Shahawy, M.I.M. and S.A.F. Hamoda (2011). The proper agricultural management practices four the new promising hybrid cotton (Giza $77 \times$ Pima S6). J. plant production, Mansoura Univ., 2(11):1551-1561

Emara M.A., S.A. Amal and S.A.F. Hamoda (2015). Effect of times and methods of potassium fertilizer on yield and yield components of new hybrid cotton (Giza $86 \times 10229$ ) under early and late sowing. Fayoum J. Agric. Res., \& Dev., 30 (1): 17 - 26.

Emara M.A.A., Amal S. Abdel-Aal and A.E. El-Gabiery (2016). Effect of sowing dates and bio-fertilizer under different NPK fertile levels on growth, yield and fiber of promising hybrid cotton Giza (86 X 10229). Egypt. J. of Appl. Sci., 31 (12): 357 - 376.

Emara, M.A. (2012). Response of cotton growth and productivity to application of potassium and zinc under normal and late sowing dates. J. Plant Production, Mansoura Univ., 3(3): 509 $-514$.

Emara, M.A. and S.A.F. Hamoda (2012). Effect of humex on growth, yield and quality of cotton under calcareous soil conditions. The $1^{\text {st }}$ Alexandria 
International Cotton Conference, Fac. of Agric., Saba Basha, Alex. Univ., Alex. 17 - 18 April, (1): 29 - 37.

Emara, M.A.A. and Amal S. Abdel-Aal (2017). Effect of nano-fertilizer on productivity of cotton under nutrient stress conditions. Egypt. J. of Appl. Sci., 32 (12B): 445 - 458.

Gomaa, M.A., F.I. Radwan; I.A. Ibrahim, M.A. Emara and A.A. Kattosh (2014). Response of Egyptian cotton to soil and foliar potassium application under calcareous soil conditions. J. Adv. Agric. Res., Fac. Agric. (Saba Basha), 19(2): 236 - 246.

Gomez, K.A and A. Gomez (1984). Statistical procedures for agricultural research. 1st ed. John Wiley Sons, New York, USA.

Hamed, F.S. (2006). Response of cotton cultivar Giza 90 to population density and nitrogen levels. Assuit J. of Agric. Sci., 37(3):173-184.

Hamoda, S.A.F. (2006). Effect of climatic conditions on bolling, earliness, yield and fiber technology in cotton. Ph. D Thesis, Fac. of Agric., Cairo Univ., Egypt, PP: 47- 49.

Hamoda, S.A.F., M.A. Ibrahim and M.A.A. Emara (2014). Effect of irrigation intervals and NPK fertilizers on growth, yield and quality for new hybrid cotton [Giza 83 (Giza 75 x 5844)] x Giza 80 . The $1^{\text {st }}$ International Cotton Conference "Challenges to Sustainable Cotton Production \& Guality". Special Issue of Egypt. J. Agric. Res., 92(1): 111 - 123.

Hearn, A.B. (1981). Cotton nutrition. Field Crop Abst., 34(1): 11 - 34.

Ibrahim, M.A.A. (2008). Effect of irrigation intervals under different NPK rates on the yield and its components on cotton. Ph. D. Thesis, Fac. of Agric., Al-Azhar Univ., Egypt.

Morteza, M., A. Slaton; E. Evans, J. McConnell; M. Fred and C. Kennedy (2005). Effect of potassium fertilization on cotton yield and petiole potassium. Summaries of Arkansas Cotton Res., pp: 74 - 78.

Pettigrew, W.T. (1999). Potassium deficiency increases specific leaf weights of leaf glucose levels in fieldgrown cotton. Agron. J., 91: 962 - 968.

Policepatil, A., B. Chittapur and V. Paramesh (2009). Response of Bt cotton hybrids for targeted yield under Northern transitional zone of Karnataka. J. of Crop and Weed. 5(1): $313-315$. 
تأثير مواعيد الزراعة ومعدلات التسميد النتروجينى والبوتاسى على نمو وإنتاجية صنف

\section{القطن جيزة 97}

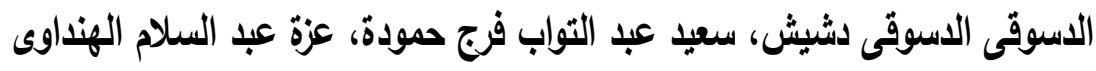

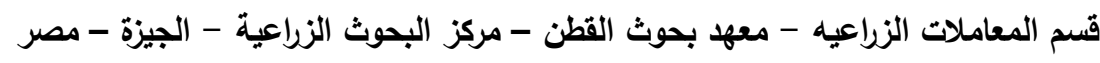

الملخص العربي

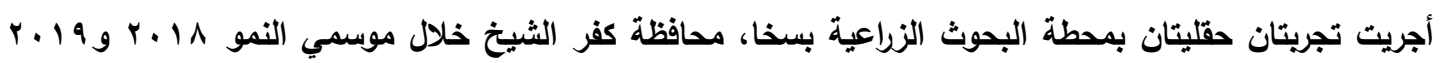

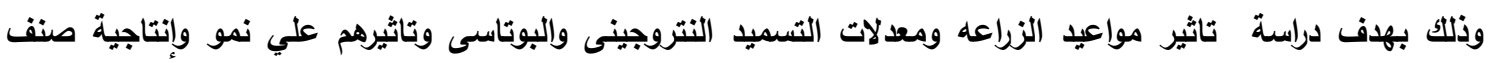

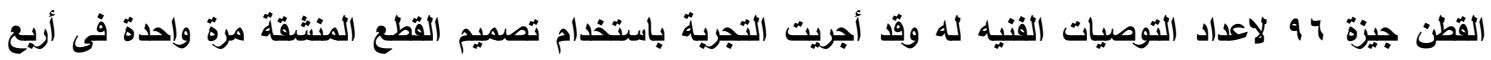

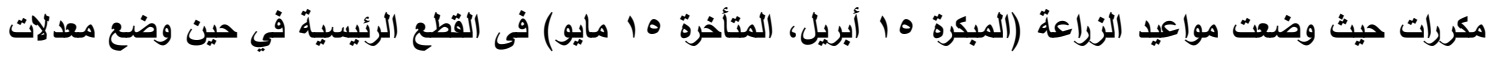

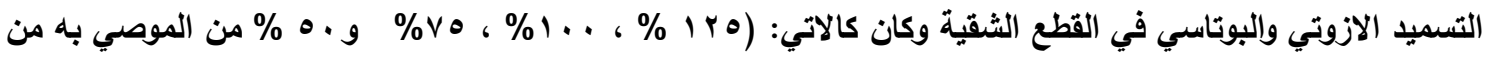

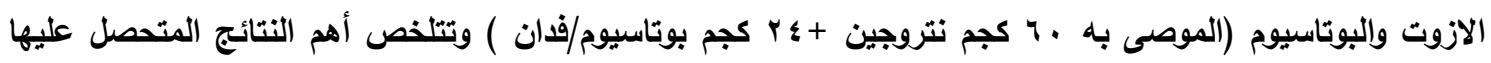

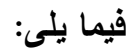

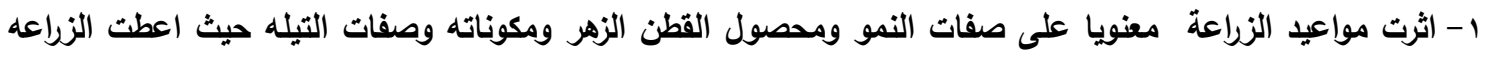

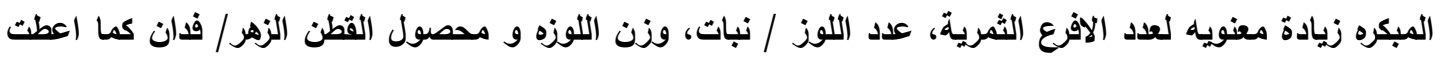
افضل القيم لصفات التيله.

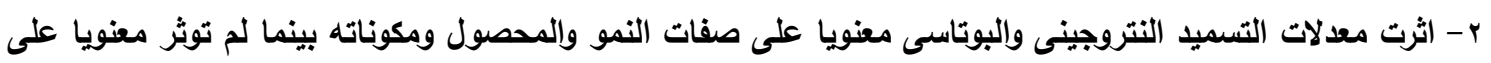

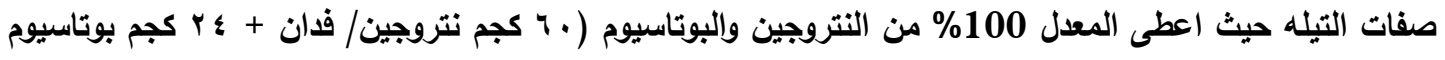

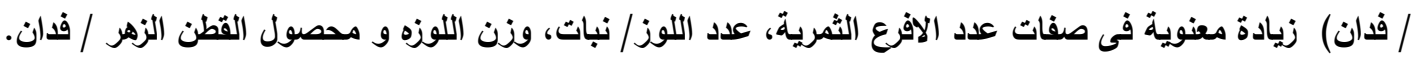

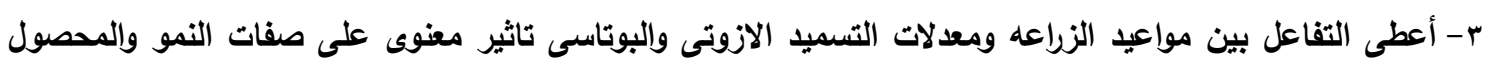

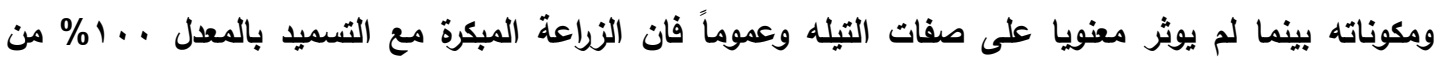

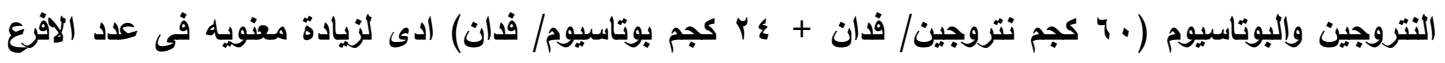

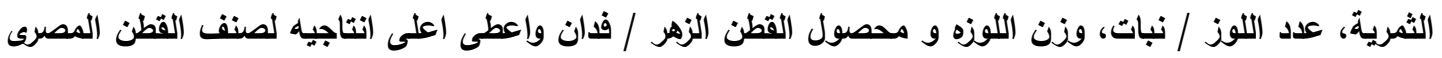

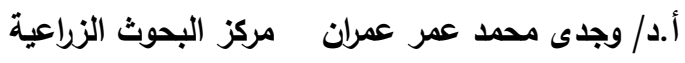

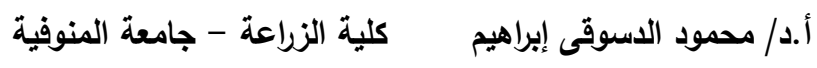

